\title{
Examination of Prospective Science Teachers' Levels of Designing Project Directed to National Support Programs: A Profile of Turkey
}

\author{
Gülşah Sezen Vekli1* \\ ${ }^{1}$ Department of Elementary Science Education, Yozgat Bozok University, Yozgat, Turkey \\ *Corresponding Author. gulsahsezen28@gmail.com
}

\begin{abstract}
This study aims to determine prospective science teachers' levels of designing projects about The Scientific and Technological Research Council of Turkey, written in the abbreviation TUBITAK's 2209-A “Support for University Students' Research Projects" and their views on the process. The study was conducted with the participation of 67 prospective science teachers. Project proposal forms and reflective reports were used in the study, which was conducted in the pedagogical activity research method- in collecting the data. The data coming from the reflective reports were then put to content analysis. It was remarkable in consequence that the majority of the prospective teachers 'levels of designing projects were inadequate. The prospective science teachers stated that they had learned the stages of scientific projects in the process of project designing and that they also became skillful at collaborating, researching, problem-solving, writing in academic language, working in a planned manner and at communicating.
\end{abstract}

Keywords National support programs, Prospective science teacher, Designing project

\section{INTRODUCTION}

One of the fundamental goals of science teaching is to raise individuals who are knowledgeable about the ways of accessing knowledge and who are capable of using scientific knowledge effectively. In other words, the goal is to raise scientifically literate individuals. Students should be provided with authentic learning environments that are rich in content, in which activities are done, which are based on real-life problems and which are research-inquiry oriented (Timur \& İmer Çetin, 2017). Activities such as national or international scientific projects in which students can participate are, undoubtedly, important at this point.

It was demonstrated by studies that developing scientific projects were influential in making them gain scientific methods (Özer \& Özkan, 2012), that it contributed to developing interest in and positive attitudes towards science (Camc1, 2008; Şahin, 2012; Çeliker \& Erduran Avc1, 2015; Yıldırım \& Şensoy, 2016) and to students' choice of a profession related to science (Fisanick, 2010; Dionne, Reis, Trudel, Guillet, Kleine \& Hancianu, 2012). On the other hand, teachers' ways of counseling and guidance to students in preparing projects are fundamental in obtaining the gains (Capraro et al., 2016).
24 October 2019

Revised: 26 November 2019

Published: 13 December 2019
Teachers are expected to monitor their students in the process of planning and implementing scientific projects and to guide them as far as possible in the process (Erdem, Uzal \& Ersoy, 2006). However, it is apparent that teachers do not comprehend the concept of guidance adequately, that they cannot lead students adequately and that they need help in this respect (Tortop, 2013; Kaplan \& Coşkun, 2012; Ünver, Arabacıoğlu \& Okulu, 2015). In addition to that, it was also found that teachers had problems in such matters as inventing an idea of the project and writing a project in the process of preparing projects (Kaplan \& Coşkun, 2012; Özel \& Akyol, 2016; Timur \& Imer Çetin, 2017).

As Oğuz Ünver, Arabacioğlu and Okulu (2015) also point out, teachers' inadequacy in their experience with and their skills at projects set considerable obstacles in front of students' process of preparing projects. Sözer (2017) states that teachers and students should be exposed to training in scientific research methods and project development so that they can develop projects of better quality. In a similar vein, Timur and Imer Çetin (2017) recommend that science teacher and prospective science teachers should be offered 
sufficient applied rather than theoretical training in project development.

It is evident that teachers who are not knowledgeable about the project development process during undergraduate education do not include project work in their professional life or that they include it in very restricted ways (Güven, 2013). It was also demonstrated through research that teachers found themselves inadequate in guiding their students in conducting a project since they had not taken a practical course on project development during their undergraduate education (Baki \& Bütüner, 2009; Bencze, 2010; Tatlı, 2016).

Prospective teachers in our country do not have training through which they can gain skills in writing such projects during their education at university nor do they have environments of experience in which they can gain skills in writing and conducting projects although several institutions- mainly scientific and technological research council of Turkey (TUBITAK) offer financial support and although there are several programs for which teachers can apply (Peten Metin, Yaman, Vekli Sezen \& Çavuş, 2019). TUBITAK offers scientists to support programs to increase the number of applications for projects. However, because such activities are limited, all the prospective teachers across the country cannot benefit from such training on projects.

On the other hand, there are hardly any studies in the literature on training prospective teachers for TUBITAK support programs, and on analyzing the effectiveness of them. Peten Metin, Yaman, Vekli Sezen \& Çavuş (2019) demonstrated that, of the TUBITAK support programs, project preparation training for 4006 science fairs and for 4007 science festival projects improved prospective science teachers' project preparation/writing skills and that they supported the prospective teachers especially in terms of choosing the types of projects and in terms of writing acceptable projects. However, no studies were found about TUBITAK 2209-A support for university students' research projects in relation to prospective science teachers.

This current study, aiming to determine prospective science teachers' levels of designing projects in relation to TUBITAK's 2209-A “Support for University Students Research Projects" and their views on the project designing process, is believed to fill the gap in the literature due to the fact that it is the first study in the literature to determine prospective science teachers' levels of designing projects within the scope of projects coded as TUBITAK 2209-A.

Considering the fact that prospective science teachers might apply for such projects in their schools upon graduation from university or that they might guide their students, it is essential to determine their levels of designing projects in exhibiting the current situation and in making the necessary modifications for their training by taking the necessary precautions.

Accordingly, this study asked prospective science teachers to design a project for the TUBITAK 2209/A support program for university students projects, and thus their project designing levels in addition to their views on the process were determined. In accordance with the purpose of the study, answers are sought to the following research questions:

1. What are the project designing levels of prospective science teachers in terms of TUBITAK 2209-A support for university students' research projects?

2. What are the views of prospective science teachers on the process of designing projects for TUBITAK 2209A support for university students' research projects?

\section{METHOD}

This study aims to determine prospective science teachers' levels of designing projects in relation to TUBITAK's 2209-A "Support for University Students' Research Projects" and their views on the process. To attain its purpose, the research was conducted in the method of pedagogical action research. Pedagogical action

Table 1 The stages followed pedagogical action research, and what is done in the process

\begin{tabular}{lll}
\hline Stages in a pedagogical action research & What is done in the process \\
\hline Step1 & $\begin{array}{l}\text { Identifying a } \\
\text { problem/paradox/difficulty } \\
\text { Searching for ways to solve the } 2 \\
\text { problem }\end{array}$ & $\begin{array}{l}\text { Informal observation } \\
\text { Focal group interviews } \\
\text { Planning the content for Technology and Project Design I course as applied. }\end{array}$ \\
Step 3 & $\begin{array}{l}\text { Performing the action } \\
\text { Designing project proposals for TUBITAK 2209-A support for university } \\
\text { students' research projects within the scope of the Technology and Project } \\
\text { Design I course } \\
\text { Writing individual reflective reports related to the experience at the end of } \\
\text { the project designing process }\end{array}$ \\
& $\begin{array}{l}\text { Evaluating the results of the action } \\
\text { plan }\end{array}$ & $\begin{array}{l}\text { Analysing the project proposals designed by prospective science teachers for } \\
\text { TUBITAK 2209-A support for university students' research projects through } \\
\text { an evaluation form } \\
\text { Analysing the reflective reports written by the prospective science teachers } \\
\text { Making recommendations on the basis of the results obtained in the study }\end{array}$ \\
& $\begin{array}{l}\text { Making modifications for future } \\
\text { research }\end{array}$ &
\end{tabular}


Table 2 Programme for training in project writing/preparation

\begin{tabular}{|c|c|c|}
\hline \multicolumn{3}{|c|}{ Programme for training in project writing/preparation } \\
\hline Weeks & Project training programme/content & Groups' duties outside classes \\
\hline 1 & $\begin{array}{l}\text { General introduction to TUBITAK 2209-A university students' } \\
\text { research projects } \\
\text { Detailed examination of project proposal forms for TUBITAK } \\
\text { 2209-A university students' research projects } \\
\text { Forming the groups }\end{array}$ & Identifying an original project subject \\
\hline 2 & $\begin{array}{l}\text { Examining the sample proposal forms for TUBITAK 2209-A } \\
\text { university students' research projects } \\
\text { Informing the prospective teachers of the evaluation process for } \\
\text { the projects coded as TUBITAK } 2209 \text {-A } \\
\text { Presenting the project subjects in the classroom and voting }\end{array}$ & Identifying an original project subject \\
\hline 3 & $\begin{array}{l}\text { How is literature review done? } \\
\text { How are problem statement, research questions and purpose } \\
\text { written in the project proposal form? } \\
\text { Presenting the project subjects in the classroom and voting }\end{array}$ & $\begin{array}{l}\text { Writing the problem statement, research questions } \\
\text { and purpose in the project proposal form }\end{array}$ \\
\hline 4 & How is eigen value written in the project proposal form? & $\begin{array}{l}\text { Writing the problem statement, research questions, } \\
\text { purpose and eigen value in the project proposal } \\
\text { form }\end{array}$ \\
\hline 5 & $\begin{array}{l}\text { How is the methodology written in the project proposal form? } \\
\text { How is the study plan written in the project proposal form? }\end{array}$ & $\begin{array}{l}\text { Writing the methodology and study plan parts in } \\
\text { the project proposal form }\end{array}$ \\
\hline 6 & How is widespread impact written in the project proposal form? & $\begin{array}{l}\text { Writing the conclusion part in the project proposal } \\
\text { form }\end{array}$ \\
\hline 7 & $\begin{array}{l}\text { How is the abstract written in the project proposal form? } \\
\text { Discussing the factors influencing the acceptance of a project } \\
\text { (eigen value, methodology, widespread impact) }\end{array}$ & $\begin{array}{l}\text { Writing the abstract part in the project proposal } \\
\text { form and giving the final shape to the proposal } \\
\text { form } \\
\text { Choosing the projects for applying }\end{array}$ \\
\hline
\end{tabular}

research involves identifying a problem or a restriction usually in a university environment or in the environment researchers work, developing a solution to it, applying the solution and monitoring and sharing the results (Norton, 2009). The study was performed in Turkey. The content of the study, which was conducted in the steps of pedagogical action research, is described below (see Table 1).

\section{Step 1. Identifying a problem/paradox/ difficulty}

The researcher observed a year ago while informing prospective science teachers of a project supported by TUBITAK (TUBITAK 2209-A Support for University Students' Research Projects) to encourage participation in the project, that the prospective teachers were not informed of the purpose, scope, and content of the project in question. The focal interviews with two different groups of prospective teachers revealed that they had not even heard of such a project before.

\section{Step 2. Searching for ways to solve the problem}

The researcher planned the content for the course Technology and Project Design I- an elective course which was taught two hours a week- in the form of project design for TUBITAK 2209-A support for university students' research projects to offer them training for preparing projects. The process was completed in seven weeks.

\section{Step 3. Performing the action}

Firstly, the prospective teachers were informed of the Technology and Project Design I course (the goal, scope, evaluation process, etc.). Secondly, they were offered general information on TUBITAK 2209-A support for university students' research projects and they were told that they would be trained in project writing/preparation for the support programme for seven weeks and that they would design a project. Information on the process of training in project preparation is shown in Table 2.

In week one of project preparation training, the project coded as TUBITAK 2209-A was introduced, the project proposal form used for the application was examined in detail and the groups to design projects were formed. In week two, the proposal forms for the accepted projects were examined and information on the evaluation process was offered. During those two weeks, the groups tried to identify original project subjects outside the classes. In week three, the groups were informed of how to review the literature and how to write the research questions and purpose of the research. Outside the classes, the groups reviewed the literature for the subjects they had identified and they wrote the research questions and the purpose of their research. In the following weeks, the prospective teachers were offered information on such parts as eigenvalue, methodology, study plan, widespread impact and abstract; and they were expected to write those parts outside the class time. They received feedback from the lecturer teaching the course throughout the process, both face to face and via e-mails. Four of the projects designed 
Table 3 Demographic properties of the prospective science teachers

\begin{tabular}{|c|c|c|c|c|c|c|c|c|c|}
\hline \multicolumn{4}{|c|}{ Second year } & \multicolumn{4}{|c|}{ Third year } & \multicolumn{2}{|l|}{ Total } \\
\hline \multicolumn{2}{|c|}{ Female } & \multicolumn{2}{|c|}{ Male } & \multicolumn{2}{|c|}{ Female } & \multicolumn{2}{|c|}{ Male } & \multirow{2}{*}{$\begin{array}{l}\text { Female } \\
\text { (n) } \%\end{array}$} & \multirow{2}{*}{$\begin{array}{l}\text { Male } \\
\text { (n) } \%\end{array}$} \\
\hline $\mathrm{n}$ & $\%$ & $\mathbf{n}$ & $\%$ & $\mathbf{N}$ & $\%$ & $\mathbf{n}$ & $\%$ & & \\
\hline 41 & 85.4 & 7 & 14.6 & 10 & 52.6 & 9 & 47.4 & $\begin{array}{l}(51) \\
76.1\end{array}$ & $\begin{array}{l}(16) \\
23.9\end{array}$ \\
\hline
\end{tabular}

Table 4 Data collection tools according to the research questions

\begin{tabular}{ll}
\hline Research questions & Data collection tools \\
\hline 1. What are the project designing & Project proposal forms \\
levels of prospective science & \\
teachers in terms of TUBITAK & \\
2209-A support for university & \\
students' research projects? & Reflective reports \\
2. What are the views of & \\
prospective science teachers on & \\
the process of designing & \\
projects for TUBITAK 2209-A & \\
support for university students' & \\
research projects?
\end{tabular}

by the groups were chosen by the lecturer to send TUBITAK.

\section{Step 4. Evaluating the results of the action plan}

The project proposals designed by the prospective teachers within the scope of this study were used as the tool of data collection. Additionally, the reports reflecting the prospective teachers' experiences in relation to the project design processes were also used for evaluation at the end of the process.

\section{Step 5. Making modifications for future research}

The necessary regulations will be made in accordance with data coming from the prospective teachers' project proposals and from their reflective reports. The regulations are shown in the recommendations part of this study.

\subsection{Participants}

67 prospective teachers (51 female and 16 male) who were the second and the third-year students and who had taken the course Technology and Project Design I took part in the research (see Table 3). Of the participants, those who were the third-year students had taken the course Scientific Research Methods whereas those who were the second-year students had not taken the course. The participants were coded as PsT1, PsT2, PsT3, PsT67.

\subsection{Data Collection Tools}

Two different tools of data collection were used in this study. One of them was the project proposal form (26) designed and prepared by prospective science teachers to determine their levels of project designing in relation to TUBITAK 2209-A “support for university students' research projects". The form was designed by TUBITAK and was shared on its official website for completing the process of application for the project.
The other data collection tool was the "reflective reports" that the prospective teachers were asked to write at the end of the designing process to determine their views on the process of project designing. The reflective report contained the instruction stated as "share the experiences you had (the parts you thought you were good at or the parts you had difficulty with/the knowledge and skills that the process caused you to gain if there are any) while designing the project proposal for 2209 support for university students' research projects within the scope of the Technology and Project Design course". In accordance with the instruction given, the participants wrote the reflective reports. Table 4 shows the distribution of the data collection tools according to the research questions.

\subsection{Support Programme for TUBITAK 2209/A University Students' Projects}

Support program for TUBITAK 2209/A university students' projects aims to encourage undergraduate students to do research through projects. The programme, which is included in the support programs of the department of science and society, provides university students with a donation for the machinery/equipment, consumables, travel and service purchasing expenses required by the research projects they prepare. Undergraduate students can apply for the program individually or in groups two times a year (in October and in March). If they apply in groups, one of the students has the responsibility as the project coordinator. A project can have 3 partners apart from the project coordinator at the maximum

\subsection{Data Analysis}

An evaluation form was developed by the researcher to evaluate the prospective science teachers' project proposal forms for TUBITAK 2209-A support for university students' research projects quantitatively.

The project evaluation form was prepared on the basis of the three basic criteria set by Science and Society Projects, in which the TUBITAK 2209-A support program for university students' research projects was also included. The three criteria were labeled as "content and transfer", "widespread impact" and "feasibility". In addition to that, the parts included in the project proposal form for TUBITAK 2209-A support for university students' research projects were also examined and thus a 22 -item evaluation form was created for the parts. Two experts in science education and chemistry education were consulted for expert opinion to attain the content validity of the evaluation form. The final shape was given to the evaluation form on the basis of the feedback coming from expert opinion. The evaluation form developed was graded and arranged (see Table 5). Accordingly, the prospective teachers received 3 points if they answered all the questions fully, they received 2 points if they answered them partially and they received 1 point if they did not have any 
Table 5 Evaluation criterion for the "feasibility" of projects

\begin{tabular}{|c|c|c|c|c|c|c|}
\hline $\begin{array}{l}\text { Evaluation } \\
\text { criteria }\end{array}$ & Stag & s of & BİTAK 2209/A Project design & & & \\
\hline \multirow{11}{*}{ 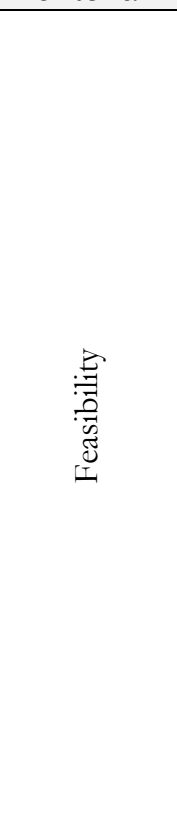 } & \multirow{8}{*}{ 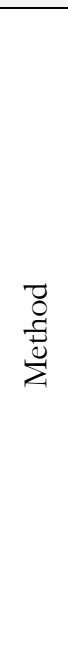 } & No & Questions & $\begin{array}{l}\text { No } \\
(1) \\
\%\end{array}$ & $\begin{array}{l}\text { Partia } \\
\text { lly } \\
(2) \\
\%\end{array}$ & $\begin{array}{l}\text { Yes } \\
(3) \%\end{array}$ \\
\hline & & 9 & Were the steps to be taken in the project planned well? & & & \\
\hline & & 10 & $\begin{array}{l}\text { Were appropriate/right measurement-evaluation instruments used to evaluate } \\
\text { the project outcome? }\end{array}$ & & & \\
\hline & & 11 & Was information on how to analyse the data coming from the project offered? & & & \\
\hline & & 12 & $\begin{array}{l}\text { Were the possibilities for infrastructure which is available/to be supplied to } \\
\text { actualise the project described? }\end{array}$ & & & \\
\hline & & 13 & $\begin{array}{l}\text { Was the scientific competence of the project team to actualise the project } \\
\text { described? }\end{array}$ & & & \\
\hline & & 14 & $\begin{array}{l}\text { Was the budgeting for infrastructure/equipment/environment to be supplied } \\
\text { done correctly? }\end{array}$ & & & \\
\hline & & 15 & $\begin{array}{l}\text { Were the precautions to be taken for hitches probable to be encountered } \\
\text { during the project described? }\end{array}$ & & & \\
\hline & \multirow{3}{*}{$\begin{array}{l}\frac{E}{J} \\
2 \\
\frac{D}{0} \\
\text { D }\end{array}$} & 16 & Was the work/package of work to be done in the study plan tabulated? & & & \\
\hline & & 17 & $\begin{array}{l}\text { Is the total length of time specified in the study plan for the project enough in } \\
\text { terms of feasibility? }\end{array}$ & & & \\
\hline & & 18 & Is the length of time for work to be done in the study plan enough? & & & \\
\hline
\end{tabular}

applications with the questions. Thus, while the maximum score receivable from the 22-item form with 3 points for each question was 66, the minimum score receivable was 22. Based on the scores received from the projects, the projects were classified as "acceptable" $(>50)$, "partially acceptable" $(30 \leq \ldots \leq 50)$ and as "unacceptable" $(\leq 30)$.

The reflective reports in which the participants individually had written their views on the process of designing projects in relation to TUBITAK 2209-A support for university students' research projects were, on the other hand, put to content analysis. Primarily, codes were created on the basis of the prospective teachers' statements written in the reflective reports. Then, the reflective reports were revised again, the frequencies and the percentages of the codes were found and then the data were tabulated. At this stage, the codes created were ranked from the highest frequency to the lowest frequency, and only the frequencies with one repetition were found. Besides, samples were quoted from the prospective teachers having the codes with the highest frequencies in the tables. Eight of the prospective teachers' reflective reports were re-coded and analyzed by an independent

Table 6 The quality of the projects developed within the scope of the course technology and project design I

\begin{tabular}{llll}
\hline \multirow{2}{*}{$\begin{array}{l}\text { The projects developed within the scope of the course } \\
\text { technology and project design } \mathbf{I}\end{array}$} \\
\cline { 2 - 4 } & Acceptable & $\begin{array}{l}\text { Partially } \\
\text { acceptable }\end{array}$ & Unacceptable \\
\hline Total & 3 & 14 & 9 \\
& $3 / 26$ & $14 / 26$ & $9 / 26$ \\
Percentages & $11.53 \%$ & $53.84 \%$ & $34.61 \%$ \\
\hline
\end{tabular}

researcher to test the reliability of the data analysis. Accordingly, an agreement between the researchers was found to be $83 \%$. Miles and Huberman (1994) state that it is considered reliable if the reliability value is above $70 \%$. Thus, reliability was attained in this context.

\section{RESULT AND DISCUSSION}

\subsection{Findings Concerning Research Question One}

The prospective teachers developed 26 projects in total. The projects were classified as "acceptable" (>50), "partially acceptable" $(30 \leq \ldots \leq 50)$ and as "unacceptable" ( $\leq 30)$ (see Table 6). According to the classification, 34.6\% of the projects developed by the participants were "unacceptable" whereas only $11.53 \%$ were "acceptable". On the other hand, approximately half of them (53.84\%) were considered to be partially acceptable.

Descriptive findings concerning the criteria in the evaluation form are presented in detail below.

\section{Analyzing the Prospective Science Teachers' TUBITAK 2209/a Project Designs in Terms of Content and Transfer}

On analyzing the students' projects in terms of content and transfer, such parts as "abstract, problem statement, research questions and the purpose" were examined (see Table 7). When the projects were analyzed from the aspect of content and transfer, it was found that the prospective science teachers were not at the adequate level in writing the abstract, in doing sufficient literature review and in stating the research questions and the purpose of the project accurately. In this context, it became evident that 
Table 7 Descriptive findings concerning the prospective science teachers' TUBITAK 2209/a project designs in terms of content and transfer

\begin{tabular}{|c|c|c|c|c|c|c|}
\hline \multirow[t]{2}{*}{$\begin{array}{l}\text { Evaluation } \\
\text { criteria }\end{array}$} & \multicolumn{6}{|c|}{ The stages of TUBITAK $2209 /$ A project design } \\
\hline & & No & Questions & $\begin{array}{l}\text { No } \\
(1) \%\end{array}$ & $\begin{array}{l}\text { Partially } \\
\text { (2) } \%\end{array}$ & $\begin{array}{l}\text { Yes } \\
(3) \%\end{array}$ \\
\hline \multirow{8}{*}{$\begin{array}{l}\text { Content and } \\
\text { transfer }\end{array}$} & Abstract & 1 & Is the purpose of the project stated? & $42 \%$ & $15 \%$ & $42 \%$ \\
\hline & & 2 & $\begin{array}{l}\text { Is the method of the project (measurement and evaluation } \\
\text { instruments, data analysis, etc.) stated? }\end{array}$ & $31 \%$ & $58 \%$ & $12 \%$ \\
\hline & & 3 & $\begin{array}{l}\text { are the ways the project will contribute to science and to the } \\
\text { society stated? }\end{array}$ & $42 \%$ & $46 \%$ & $12 \%$ \\
\hline & $\begin{array}{l}\text { Problem } \\
\text { statement }\end{array}$ & 4 & $\begin{array}{l}\text { Was problem statement appropriate to the project } \\
\text { summon formulated? }\end{array}$ & $27 \%$ & $23 \%$ & $50 \%$ \\
\hline & & 5 & $\begin{array}{l}\text { was sufficient literature reviewed in presenting the problem } \\
\text { statement? }\end{array}$ & $38 \%$ & $46 \%$ & $15 \%$ \\
\hline & Research & 6 & Are the research questions of researchable quality? & $35 \%$ & $23 \%$ & $42 \%$ \\
\hline & questions & 7 & $\begin{array}{l}\text { Are the research questions accurate in scientific/academic } \\
\text { language? }\end{array}$ & $38 \%$ & $27 \%$ & $35 \%$ \\
\hline & Purpose & 8 & $\begin{array}{l}\text { Is the purpose of the project scientifically/academically } \\
\text { accurate? }\end{array}$ & $58 \%$ & $19 \%$ & $23 \%$ \\
\hline
\end{tabular}

Table 8 Descriptive findings concerning the prospective science teachers' TUBITAK 2209/a project designs in terms of feasibility

\begin{tabular}{|c|c|c|c|c|c|c|}
\hline $\begin{array}{l}\text { Evalua- } \\
\text { tion } \\
\text { Criteria }\end{array}$ & $\begin{array}{l}\text { Stages of } \\
\text { project } \\
\text { design }\end{array}$ & No & Questions & $\begin{array}{l}\ominus \\
\stackrel{0}{Z} \circ^{\circ}\end{array}$ & : & 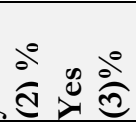 \\
\hline \multirow{10}{*}{$\begin{array}{l}\text { Feasi- } \\
\text { bility }\end{array}$} & \multirow{7}{*}{$\begin{array}{l}\text { Methodo- } \\
\text { logy }\end{array}$} & 9 & Are the stages to be followed in the project planned well? & $54 \%$ & $31 \%$ & $15 \%$ \\
\hline & & 10 & $\begin{array}{l}\text { Are the appropriate/accurate measurement-evaluation } \\
\text { instruments used to evaluate the project outcomes? }\end{array}$ & $54 \%$ & $23 \%$ & $23 \%$ \\
\hline & & 11 & $\begin{array}{l}\text { Is the information given on how to analyse the data collected in } \\
\text { the project? }\end{array}$ & $81 \%$ & $15 \%$ & $4 \%$ \\
\hline & & 12 & $\begin{array}{l}\text { Are the infrastructure/equipment possibilities available/needing } \\
\text { to be supplied to conduct the project stated? }\end{array}$ & $73 \%$ & $23 \%$ & $4 \%$ \\
\hline & & 13 & $\begin{array}{l}\text { Is the scientific competence and occupational experience of the } \\
\text { project team to conduct to project stated? }\end{array}$ & $69 \%$ & $27 \%$ & $4 \%$ \\
\hline & & 14 & $\begin{array}{l}\text { Is the budgeting for the infrastructure/equipment/environment } \\
\text { to be supplied for the project done accurately? }\end{array}$ & $73 \%$ & $23 \%$ & $4 \%$ \\
\hline & & 15 & $\begin{array}{l}\text { Are the precautions to be taken for hitches probable to be } \\
\text { experienced in the project stated? }\end{array}$ & $100 \%$ & $0 \%$ & $0 \%$ \\
\hline & \multirow[t]{3}{*}{ Study plan } & 16 & $\begin{array}{l}\text { Is the work/package of work to be done in the study plan } \\
\text { tabulated? }\end{array}$ & $35 \%$ & $46 \%$ & $19 \%$ \\
\hline & & 17 & $\begin{array}{l}\text { Is the total length of time specified in the study plan for the } \\
\text { project sufficient in terms of feasibility? }\end{array}$ & $58 \%$ & $31 \%$ & $12 \%$ \\
\hline & & 18 & $\begin{array}{l}\text { Is the length of time specified sufficient for the work to be done } \\
\text { in the study plan? }\end{array}$ & $58 \%$ & $35 \%$ & $8 \%$ \\
\hline
\end{tabular}

the participants did not state the purpose of the project $(42 \%)$ and that they did not explain the way the project would contribute to science and to the society $(42 \%)$. It was remarkable that they did not review sufficient literature $(38 \%)$.

In a similar vein, more than half of the prospective teachers $(58 \%)$ did not state the purpose of their project accurately. In addition to that, it was also remarkable that they had problems in formulating research questions of researchable quality $(38 \%)$.
Analyzing the Prospective Science Teachers' TUBITAK 2209/a Project Designs in Terms of Feasibility

The methodology and study plan of the projects were analyzed from the aspect of feasibility. Accordingly, it became apparent that the majority of the prospective teachers had problems in writing the methodology and study plan parts of their projects (see Table 8). It was found that the prospective science teachers were not adequate in planning the stages to be followed in the process of project making (54\%), in using the appropriate evaluation 
Table 9 Descriptive findings concerning the prospective science teachers' TUBITAK 2209/A project designs in terms of widespread impacts

\begin{tabular}{|c|c|c|c|c|c|c|}
\hline $\begin{array}{l}\text { Evaluation } \\
\text { criteria }\end{array}$ & $\begin{array}{l}\text { Stages of } \\
\text { project design }\end{array}$ & No & Questions & $\begin{array}{l}\text { No } \\
\text { (1) } \\
\%\end{array}$ & $\begin{array}{l}\text { Partially } \\
\text { (2) } \%\end{array}$ & $\begin{array}{l}\text { Yes } \\
(3) \%\end{array}$ \\
\hline \multirow[t]{4}{*}{$\begin{array}{l}\text { Widespread } \\
\text { impacts }\end{array}$} & \multirow[t]{2}{*}{$\begin{array}{l}\text { Results/widespr } \\
\text { ead impacts }\end{array}$} & 19 & $\begin{array}{l}\text { Are the ways the project outcomes will contribute to } \\
\text { science and to the society stated? }\end{array}$ & $38 \%$ & $42 \%$ & $19 \%$ \\
\hline & & 20 & $\begin{array}{l}\text { Are the ways to share the project outcomes with large } \\
\text { masses stated? }\end{array}$ & $73 \%$ & $8 \%$ & $19 \%$ \\
\hline & \multirow[t]{2}{*}{ Resources } & 21 & $\begin{array}{l}\text { Are all the resources used in preparing the project proposal } \\
\text { form stated? }\end{array}$ & $69 \%$ & $15 \%$ & $15 \%$ \\
\hline & & 22 & $\begin{array}{l}\text { Are the resources used in preparing the project proposal } \\
\text { form written academically correctly? }\end{array}$ & $62 \%$ & $31 \%$ & $8 \%$ \\
\hline
\end{tabular}

Table 10 The stages with which the prospective science teachers had difficulty in designing the projects, and sample quotations from their statements

\begin{tabular}{|c|c|c|}
\hline $\begin{array}{l}\text { Stages with this they had } \\
\text { difficulty }\end{array}$ & $\begin{array}{l}\text { f } \\
(n: 67)\end{array}$ & Examples from their statements \\
\hline $\begin{array}{l}\text { Specifying an original project } \\
\text { subject }\end{array}$ & $48 \%$ & $\begin{array}{l}\text { PsT14: "I had great difficulty inspecifying the problem statement because the problem statements } \\
\text { I found had been found by others before and studies had been performed about them." } \\
\text { PsT22: "firstly, we had a little difficulty in choosing our project." } \\
\text { PsT26: "we primarily had a little difficulty in finding an idea for the project because it needed to } \\
\text { be both original and researchable." } \\
\text { Ö61: "we had difficulty in specifying the project subject because the project should be original, } \\
\text { designable and useful." }\end{array}$ \\
\hline Writing about methodology & $25 \%$ & $\begin{array}{l}\text { PsT34: "the part we had difficulty in preparing this project proposal was the methodology part..." } \\
\text { PsT50: "... but we had certain difficulties in writing about the methodology because methodology } \\
\text { needed to include the whole project. We needed to plan and list everything from the description of } \\
\text { the problem to the conclusion step by step." }\end{array}$ \\
\hline Academic writing & $9 \%$ & $\begin{array}{l}\text { PsT48: "I felt inadequate in using academic language in writing the project and I had difficulty } \\
\text { in it." } \\
\text { PsT59: "I personally had difficulty in putting the project to writing because I had difficulty in } \\
\text { making sentences in academic language since it was my first experience." }\end{array}$ \\
\hline Preparing a study plan & $7.4 \%$ & $\begin{array}{l}\text { PsT14: "But in preparing the work package, especially, I had difficulty in expressing them in } \\
\text { tables or graphs, in dividing them into months and in deciding on devoting time to each item." } \\
\text { PsT42: "we also had difficulty in the final part-in the work package- because we were naturally } \\
\text { delayed in finishing the project when we had more stages to follow in each month." }\end{array}$ \\
\hline $\begin{array}{l}\text { Most of the stages of a } \\
\text { scientific project }\end{array}$ & $7.4 \%$ & $\begin{array}{l}\text { PsT20: "the part I had difficulty with was the preparation of the stages of the project." } \\
\text { PsT63: "Most of the time I had difficulty in what stages to follow in writing the project and in } \\
\text { how to write the project." }\end{array}$ \\
\hline Reviewing the literature & $6 \%$ & $\begin{array}{l}\text { PsT21: "I had difficulty in reviewing the literature and the resources because there were lots of } \\
\text { resources and I had difficulty in reviewing the ones appropriate for our project." } \\
\text { PsT49: "Another part I had difficulty was the literature review part. I had difficulty in including } \\
\text { in the project what we found while investigating what had been done about the subject we worked } \\
\text { on and who else had studied the subject". }\end{array}$ \\
\hline $\begin{array}{l}\text { Writing about widespread } \\
\text { impacts }\end{array}$ & $6 \%$ & $\begin{array}{l}\text { PsT48: "we had difficulty in finding where we could use a game assuming that games had effects } \\
\text { after using the game." } \\
\text { Ö66: "we all had difficulty in writing the widespread impacts." }\end{array}$ \\
\hline Group work & $4.5 \%$ & $\begin{array}{l}\text { PsT28: "we had difficulty in agreement with my friends in the group while completing the project } \\
\text { proposal." } \\
\text { PsT41: "We mostly had difficulty in acting as a group". }\end{array}$ \\
\hline Writing the purpose & $3 \%$ & PsT44: "... We also had difficulty in writing the purpose of the project." \\
\hline $\begin{array}{l}\text { Formulating the research } \\
\text { questions }\end{array}$ & $3 \%$ & $\begin{array}{l}\text { PsT48: "I had difficulty in formulating the research questions in the project because I thought the } \\
\text { questions would be more general." }\end{array}$ \\
\hline
\end{tabular}

instruments to evaluate the project outcomes (54\%), in informing on how to analyze the collected data (81\%) and in informing on the infrastructure/equipment possibilities which are available or which need to be supplied (73\%).
Besides, it was also found that the project team was not adequate in stating their competence $(69 \%)$, in budgeting the project expenses accurately $(73 \%)$ and in specifying the appropriate length of time for each activity in the study 
Table 11 The stages at which the prospective science teachers were good in designing the projects, and sample quotations from their statements

\begin{tabular}{|c|c|c|}
\hline Stages of project & $\begin{array}{l}\text { f } \\
(n: 67)\end{array}$ & Examples from their statements \\
\hline $\begin{array}{l}\text { Specifying an original } \\
\text { project subject }\end{array}$ & $10.4 \%$ & $\begin{array}{l}\text { PsT6: "the part we were good at was.... We had good ideas } \\
\text { PsT46: "T think we were good at the parts where we specified the problem statement." }\end{array}$ \\
\hline Writing the purpose & $9 \%$ & PsT47: "I think we were good at stating the purpose of the project." \\
\hline $\begin{array}{l}\text { Working in coordination in } \\
\text { groups }\end{array}$ & $9 \%$ & PsT5: "...I think I worked in coordination with my friends in the group $n$ the process." \\
\hline Preparing packages of work & $6 \%$ & PsT57: "... the part we did best was to prepare the timetable for work." \\
\hline $\begin{array}{l}\text { Formulating the research } \\
\text { questions }\end{array}$ & $6 \%$ & PsT4: "the part we were the best at was the research questions." \\
\hline Writing abstracts & $6 \%$ & $\begin{array}{l}\text { PsT14: "T had no difficulty in the abstract because it was written after all the project work had } \\
\text { finished." }\end{array}$ \\
\hline Writing about methodology & $6 \%$ & $\begin{array}{l}\text { PsT67: "I liked preparing the package of work very much. I think was good at writing about the } \\
\text { methodology." }\end{array}$ \\
\hline Literature review & $3 \%$ & PsT60: ...we did the literature review effectively with my partners." \\
\hline $\begin{array}{l}\text { Writing the widespread } \\
\text { impacts }\end{array}$ & $3 \%$ & $\begin{array}{l}\text { PsT50: "I didn't have any difficulty in writing the widespread impacts because I think that we } \\
\text { reflected well the information on how to use the results across the country and across the world" }\end{array}$ \\
\hline
\end{tabular}

plan $(58 \%)$ and for all the activities (58\%). It was also found that the prospective science teachers did not state the precautions which might be taken for hitches to arise in the process of conducting the project in any of the projects.

Analyzing the Prospective Science Teachers' TUBITAK 2209/a Project Designs in Terms of Widespread Impact

The results/widespread impacts of the projects were analyzed in the criterion of widespread impacts. On analyzing the projects from the aspect of widespread impacts, it was found that the majority of the prospective science teachers $(73 \%)$ did not offer information on how to share the project outcomes with large masses (see Table 9). In most of the projects, on the other hand, it was found that the resources used in the process were not stated $(69 \%)$ and that the resources were not written correctly academically $(62 \%)$.

\subsection{Findings Concerning Research Question Two}

The Stages with Which the Prospective Science Teachers Had Difficulty

It was found on examining the reflective reports that the prospective teachers had difficulty in specifying an original project subject, in writing about the methodology, in academic writing, in preparing a study plan and in the literature review (see Table 10). A detailed examination of these themes demonstrated that almost half of the prospective teachers $(48 \%)$ had difficulty in specifying an original project subject in relation to TUBITAK 2209-A support for university students' research projects. Additionally, they also stated that they had difficulty in expressing such scientific project stages as methodology, work package, literature, widespread impacts and formulating research questions and writing the purpose of the project in academic language.

DOI: $10.17509 / j s l . v 3 i 2.20740$
The Stages that the Prospective Science Teachers Thought They were Good

On examining the stages that the prospective teachers thought they were good in the process of project design, such themes as specifying original project subjects, writing the purpose of the project, working in coordination groups, preparing work packages, writing research questions, writing abstracts, reviewing the literature and writing the widespread impacts were found to be remarkable (see Table 11). Only a small number of prospective science teachers thought that they were good at writing the stages of a scientific project in the process of project design. For instance, $10.4 \%$ said that they were good at specifying an original project subject. On the other hand, they were found to think that they were good at writing about the methodology $(6 \%)$, preparing package of work $(6 \%)$, reviewing the literature $(3 \%)$, writing the widespread effects $(3 \%)$, formulating the research questions $(6 \%)$ and writing the purpose $(6 \%)$.

Table 12 gives a summary of the knowledge and skills the prospective science teachers gained in the process of designing projects. Accordingly, the prospective teachers stated that they learned the stages of a scientific project $(41.8 \%)$ and that they became skillful at collaborating $(27 \%)$, doing research $(17.9 \%)$, problem-solving $(17.9 \%)$, writing in academic language (11.9\%), working according to a plan $(11.9 \%)$ and communicating $(9 \%)$ in the process of designing projects (see Table 12). A small number of them, however, said that they gained skills in multidimensional thinking and in creative thinking. Some of them, on the other hand, said that they learned such things as writing the references and preparing the package of work. 
Table 12 Knowledge and skills the prospective science teachers gained in the process of project design, and sample quotations from their statements

\begin{tabular}{|c|c|c|}
\hline $\begin{array}{l}\text { Knowledge and Skills } \\
\text { gained }\end{array}$ & $\begin{array}{l}\text { f } \\
(\mathrm{n}: 67)\end{array}$ & Examples from their statements \\
\hline $\begin{array}{l}\text { Stages of preparing a } \\
\text { scientific project (research } \\
\text { questions, widespread } \\
\text { impacts, feasibility) }\end{array}$ & $41.8 \%$ & $\begin{array}{l}\text { PsT19: "I was informed of how to write a project. I learnt about what should be cared in writing a } \\
\text { project, how to prepare a project, research methods used in a project and how to form the content } \\
\text { PsT25: "I think I learnt about the stages from research problem to justifications, purpose, } \\
\text { bypotheses, methodology and conclusion." } \\
\text { Ö58: "I learnt what I should pay attention to while preparing a project and what properties a project } \\
\text { should have (widespread impact, originality, feasibility, meeting a need, economy, etc.). most } \\
\text { importantly, I learnt how to write a project. }\end{array}$ \\
\hline Collaborating & $27 \%$ & $\begin{array}{l}\text { Ps'T24: "... it taught me how to work in division of work, and how to apply it." } \\
\text { Ps'T37: "it secured working in groups in coordination in a project and sharing the work voluntarily } \\
\text { and achieving group success." }\end{array}$ \\
\hline Skills in doing research & $17.9 \%$ & $\begin{array}{l}\text { PsT19: "I learnt how to do comprehensive research." } \\
\text { PsT30: "I learnt to do research based on various resources." }\end{array}$ \\
\hline Problem-solving & $17.9 \%$ & $\begin{array}{l}\text { PsT18: "what we gained from it: we learnt how to find solutions to the problems we encounter." } \\
\text { PsT65: "we designed a project about the problem we specified in the scope of this } \\
\text { course. I can say we improved our problem solving skills." }\end{array}$ \\
\hline $\begin{array}{l}\text { Writing in academic } \\
\text { language }\end{array}$ & $11.9 \%$ & PsT10: "T learnt to write a project draft in academic language." \\
\hline Working according to a plan & $11.9 \%$ & $\begin{array}{l}\text { PsT38: "I understood that preparing a project was a demanding job and that it required a lot of } \\
\text { research and regular and disciplined work in order for it to be original." }\end{array}$ \\
\hline Communication skills & $9 \%$ & $\begin{array}{l}\text { PsT35: "it contributed to our communicating effectively with our partners in the group while } \\
\text { designing a project idea and while talking to others." }\end{array}$ \\
\hline $\begin{array}{l}\text { Preparing package of } \\
\text { work/work schedule }\end{array}$ & $7.4 \%$ & PsT52: "..... t made us gain skills in what way to pursue while preparing a study plan." \\
\hline Multi-dimensional thinking & $4.5 \%$ & $\begin{array}{l}\text { PsT4: "designing projects tanght me to think broadly and to analyse a problem from different } \\
\text { perspectives." }\end{array}$ \\
\hline Creative thinking skills & $3 \%$ & PsT13: "I think I gained the skill to think creatively in this course." \\
\hline Writing the references & $3 \%$ & PsT19: "I learnt how to prepare the references part." \\
\hline $\begin{array}{l}\text { Setting up cause and effect } \\
\text { relationships }\end{array}$ & $3 \%$ & PsT37: “... I learnt to set up cause-effect relationships and to generate original ideas." \\
\hline Self- confidence & $3 \%$ & Ps'T56: "the fact that our project was chosen and sent to TUBITAK increased my self-confidence." \\
\hline
\end{tabular}

\subsection{Discussion}

This study was conducted to determine prospective science teachers' levels of project design and their views on the process of project design in relation to TUBITAK 2209-A support for university students' research projects. According to the results, the fact that a small proportion of the projects $(11.56 \%)$ were acceptable demonstrated that the majority of the prospective teachers were inadequate in terms of designing projects. This was a result in parallel to the ones obtained by Baki and Bütüner (2009), by Bencze (2010) and by Tatl (2016). Considering the fact that the majority of the prospective teachers had prepared project proposals for the first time and that they had not taken a course in research methods $(70 \%)$, the result could be regarded as natural.

Another result obtained in this study demonstrated that the feasibility of the projects developed by the prospective science teachers was inadequate. For example, they were found to have problems in planning the process of project design, in choosing appropriate evaluation instruments to evaluate the project outcomes and in stating the length of time needed and the materials which are available/ which should be supplied to actualize the project. Their views that they had difficulty in writing the methodology part in their reflective reports were also supportive of this result. In a similar way, it might have stemmed from the fact that most of the participants had not taken a course in scientific research methods. Considering the length of the course Technology and Project Design 1 (two hours a week), the fact that in-depth information was not offered about scientific research methods could be understood. Therefore, it may be recommended that a similar study be repeated with students who have taken a course in scientific research methods and that the results obtained to be compared with the ones obtained in this current study.

On the other hand, the fact that the course Technology and Project Design 1 was included in the second-year curriculum and that the course Scientific Research Methods was included in the third-year curriculum might have influenced the effectiveness of the project training in negative ways. Thus, it can be recommended that the 
undergraduate program for the science teaching department should be re-arranged by taking this factor into consideration.

It was found in this study that the prospective science teachers could not specify the problem statement appropriately to the project summon or that they could not state it inappropriate academic language. The data coming from the reflective reports also demonstrated that they had difficulty in this respect. Relevant literature also shows that the greatest problem prospective science teachers had in developing projects was "failure to generate a new idea/to find a project subject" (Oğuz Ünver, Arabacioğlu \& Okulu, 2015; Özel \& Akyol, 2016; Timur \& Imer Çetin, 2017). Project support programs for which teachers can apply individually and in which they need to guide their students which are supported by several institutions-mainly by TUBITAK are available in Turkey. When seen from this perspective, it might be influential for prospective teachers to receive pre-service training about projects and to have experience in such project designing and coordinating programs so that they can gain skills in designing and coordinating projects (Timur \& Imer Çetin, 2017).

\section{CONCLUSION}

The results obtained from the prospective teachers' reflective reports demonstrated that they gained such different skills as collaborating, researching, problemsolving, writing in academic language, working according to a plan and communicating in addition to learning about the stages of scientific projects. It was a finding in parallel to the one obtained by Peten Metin, Yaman, Vekli Sezen \& Çavuş (2019), who analyzed the effects of TUBITAK's support project preparation training (coded as 4006 and 4007) on prospective science teachers' project writing/preparation skills. This study could not determine prospective science teachers' levels of project design prior to project training for support coded as 2209 because it was found as mentioned earlier that the prospective teachers did not have any prior knowledge about the support program. A similar study could be performed with two groups who are knowledgeable about the support program coded as 2209-A by using the experimental method with a control group, and thus the effectiveness of project training in terms of different variables could be demonstrated more concretely.

\section{REFERENCES}

Baki, A., \& Bütüner, S. Ö. (2009). Kırsal kesimdeki bir ilköğretim okulunda proje yürütme sürecinden yansımalar. İlköğretim Online, $8(1), 2-14$.

Bencze, J. L. (2010). Promoting student-led science and technology projects in elementary teacher education: Entry into core pedagogical practices through technological design. International Journal of Technology and Design Education, 20(1), 43-62.

Camcı, S. (2008). Bilim șenliğine katılan ve katılmayan ögrencilerin bilim ve bilim insanlarma yönelik ilgi ve imajlarmın karşılaștırlmast. Hacettepe Üniversitesi, Ankara.
Capraro, R. M., Capraro, M. M., Scheurich, J. J., Jones, M., Morgan, J., Huggins, K. S., ... \& Han, S. (2016). Impact of sustained professional development in STEM on outcome measures in a diverse urban district. The Journal of Educational Research, 109(2), 181196.

Çeliker, D., \& Erduran Avci, D. D. D. (2015). İlkokul Öğrencilerinin Bilim İnsanı Algıları: Öğrencilerin Bilimsel Faaliyetlere Katılması Bilim İnsanı Algıların Nasıl Etkiler?. Mehmet Akif Ersoy Üniversitesi Eğitim Fakültesi Dergisi, 1(36), 90-104.

Dionne, L., Reis, G., Trudel, L., Guillet, G., Kleine, L., \& Hancianu, C. (2012). Students'sources of Motivation for Participating in Science Fairs: An Exploratory Study Within the Canada-Wide Science Fair 2008. International journal of science and mathematics education, 10(3), 669693.

Erdem, A., Uzal, G., \& Ersoy, Y. (2006). Fen Bilgisi/Fizik Öğretmenlerinin Eğitim Sorunları: Gelişmeleri Sürekli İzlemeleri ve Gerekli Yenilikleri Edinmeleri. Araștırma Raporu, TFV Yaymı, Tekirdă.

Fisanick, L. M. (2010). A descriptive study of the middle school science teacher behavior for required student participation in science fair competitions.

Güven, I. (2013). Fen ve teknoloji öğretmen adaylarının proje yönetimi deneyimlerinin değerlendirilmesi [Evaluation of prospective science and technology teachers' experiences of project management in Turkish][Special Issue]. Hacettepe University Journal of Education, 1, 204-218.

Huberman, A. M., \& Miles, M. B. (1994). Data management and analysis methods. In N. K. Denzin \& Y. S. Lincoln (Eds.), Thousand Oaks, CA, US: Sage Publications, Inc.

Kaplan, A. Ö., \& Coşkun, Y. D. (2012). Proje tabanlı öğretim uygulamalarında karşılaşılan güçlükler ve çözüm önerilerine yönelik bir eylem araştırması. Mersin Üniversitesi Ë̆itim Fakültesi Dergisi, 8(1), 137-159.

Norton, L. (2018). Action research in teaching and learning: A practical guide to conducting pedagogical research in universities. Routledge.

Özel, M., \& Akyol, C. (2016). Bu benim eserim projeleri hazırlamada karşılaşılan sorunlar, nedenleri ve çözüm önerileri. Gą̧i Üniversitesi Gazi Eğitim Fakültesi Dergisi, 36(1).

Özer, D. Z., \& Özkan, M. (2012). Proje tabanlı öğretimin fen bilgisi öğretmen adaylarının bilimsel süreç becerileri üzerine etkisi. Journal of Turkish Science Education, 9(3), 119-130.

Peten Metin, D., Yaman, F., SezenVekli, G. \& Çavuş, M. (2019). Improving preservice science teachers' ability to write/prepare projects to TUBITAK grant program. International Journal of Social Sciences and Education Research, 5(1), 78-90.

Şahin, Ş. (2012). Bilim şenliklerinin 10. sınıf öğrencilerinin kimya dersine yönelik tutumlarına olan etkisi. Ușak Üniversitesi Sosyal Bilimler Dergisi, 5(1), 89-102.

Sözer, Y. (2017). Investigation of the project development process of the pupils who attend to the Tubitak research project contest: an action research. Inonu University Journal of the Faculty of Education, 18(2), 139-158.

Tatli, Z. (2016). Proje Geliştirme Sürecine Dair Öğretmen Görüşleri. Yüzüncü Yal Üniversitesi Eğitim Fakültesi Dergisi, 13(1), 631-656.

Timur, B., \& İmer Çetin, N. (2017). Fen ve Teknoloji Öğretmenlerinin Proje Geliştirmeye Yönelik Yeterlikleri: Hizmet içi Eğitim Programinin Etkisi. Journal of Kirsebir Education Faculty, 18(2).

Tortop, H. S. (2013). Science teachers' views about the science fair at primary education level. Turkish Online Journal of Qualitative Inquiry, $4(2), 56-64$.

Ünver, A. O., Arabacioğlu, S., \& Okulu, H. Z. (2015). Öğretmenlerin bu benim eserim proje yarışması rehberlik sürecine ilişkin görüşleri. Muğla Sitkı Koçman Üniversitesi Eğitim Fakültesi Dergisi, 1(3).

Yıldırım, H. İ., \& Şensoy, Ö. (2016). Bilim şenliklerinin 6. sınıf öğrencilerinin fen bilimleri dersine yönelik tutumlarına etkisi. Türk Eğitim Bilimleri Dergisi, 14(1), 23-40. 